\title{
High Performance Work Systems, Person-Organization Fit and Organizational Outcomes
}

\author{
Jun Woo Lee (Corresponding author) \\ College of Business and Economics \\ Hanbat National University \\ 16-1, Duckmyong-dong, Yuseong-gu \\ Daejeon, 305-719, Korea (ROK) \\ Tel: 82-42-821-1297Ｅ-mail: leejw@hanbat.ac.kr \\ Hojin Bang \\ Business School, Sungkyunkwan University \\ 25-2, Sungkyunkwan-ro, Seoul, 110-745, Korea (ROK) \\ Tel: 82-10-2291-0352_E-mail: akira9374@gmail.com
}

Received: May 21, 2012

doi:10.5430/jbar.v1n2p129
Accepted: December 12, 2012

Online Published: December 14, 2012

URL: http://dx.doi.org/10.5430/jbar.v1n2p129

\begin{abstract}
Previous studies on human resource management have emphasized the relationship between high performance work systems (HPWSs) and organizational performance in strategic human resource management. The extant literature on the intermediate linkage between HPWSs and performance has yield only limited insights into the influence of the use of HPWSs on performance at the organizational level. Also, little attention has been paid to conceptual constructs such as person-organization (P-O) fit as a mediator between the HPWSs and organizational outcomes. Thus, this paper attempts to explore how the linkage of the HPWSs to P-O fit as a mediating variable leads to organizational outcomes. From the literature review, it is proposed that the congruence of workers with their organization positively affects organizational outcomes when it is linked to specific systems. The paper suggests that an organization can improve P-O fit not through control-oriented systems but through high commitment work systems. It concludes with a presentation of three principal propositions associated with HPWSs, P-O fit and organizational outcomes.
\end{abstract}

Keywords: High performance work system, Person-Organization (P-O) fit, Organizational outcomes

\section{Introduction}

High performance work systems (HPWSs) have often been regarded as systems that promote employee commitment and autonomy in strategic human resource management (SHRM). The HPWSs assume that employees are a primary source of competitive advantages that is difficult to imitate. Moreover, workers can create continuous improvement and perform at a higher level if they are motivated to do so. This is achieved by encouraging practices such as participatory decision making, providing high-quality training and sharing information. By treating workers with respect and as capable and intelligent individuals, organizations find that workers are more committed to the organization and more trustful of management, which will result in improved performance (Walton, 1985).

Then, under what conditions do firms with a high performance work system show high organizational performance? It is presumed that firms adopting a high performance work system may produce high organizational performance in workplaces where the employees have high internal motivation. Questions can be raised regarding the direct effect of the high performance work system on organizational outcomes. To answer these questions, this paper explores the linkage of the HWPSs to person-organization (P-O) fit in firms. It has been suggested that the employee's attitudes and behaviors mediate the relationship between HWPSs and individual/organizational performance. In this vein, this linkage can be extended to the notion of $\mathrm{P}-\mathrm{O}$ fit.

This paper examines the relationship of HPWSs and organizational outcomes, and attempts to explain the mediating effects of P-O fit. To this end, it examines the logic of the underlying theories or assumptions and reviews their 
applicability. It is proposed that the congruence of workers with their organization (or organizational culture) is positively associated with organizational outcomes or performance. Organizations often try to develop workforce flexibility and commitment by instilling a P-O fit, which refers to the compatibility between people and the organization in which they work (Schneider, 1987; Bowen, Ledford, \& Nathan 1991; Kristof, 1996). Achieving high levels of P-O fit through hiring and socialization is often touted as the key to retaining a workforce with the flexibility and organizational commitment necessary to meet competitive challenges (Kristof, 1996). This paper seeks to find how the relationship between appropriate P-O fit level and HPWSs influences organizational outcomes.

\section{Literature Review and Theory}

\subsection{High Performance Work Systems}

High performance work systems have attracted attention from academics and practitioners as a tool to improve organizational performance and employee outcomes such as work satisfaction and to lower job stress (Preuss, 2003). However, neither conceptual perspective (e.g., Lawler, 1992; Pfeffer, 1998) nor empirical work (e.g., Arthur, 1994; Huselid, 1995) provides a precise definition of high performance work systems. These systems include practices such as rigorous selection procedures, internal merit-based promotions, grievance procedures, cross-functional and cross-trained teams, high levels of training, information sharing, participatory mechanisms, group-based rewards, and skill-based pay.

There have been diverse arguments about HPWSs among HRM authors. For example, Pfeffer(1998) identified seven key dimensions: employment security; selective hiring of new personnel; self-managed teams and decentralization of decision making as the basic principles of organizational design; comparatively high compensation contingent on organizational performance; extensive training; reduced status distinctions and barriers; and the extensive sharing of financial and performance information throughout the organization. In the HPWSs, workers are, to a larger degree, self-controlled and self-managed (Tomer, 2001). The HPWSs is conceptualized as a set of distinct but interrelated HRM practices that together select, develop, retain, and motivate a workforce (e.g., Huselid, 1995; Becker \& Huselid, 1999; Guthrie, 2001). The workers who possess superior abilities tend to apply their competence to work-related activities. The work-related activities (i.e., actual employee behaviors/output) result in achieving superior intermediate indicators of firm performance and sustainable competitive advantage (Way, 2002).

Numerous studies provide empirical support for the superiority of HPWSs for employees and organization level performance (e.g., Arthur, 1992, 1994; Huselid, 1995; MacDuffie, 1995; Messersmith \& Guthrie, 2010; Ichniowski, Shaw, \& Prennushi et al., 1997; Way, 2002; Wood, Van Veldhoven, Croon, \& de Menezes, 2012; Zacharatos, Barling, \& Iverson 2005). The earlier literature on HRM tended to posit the notion that introducing HRM within an organization would lead to improvements in organizational effectiveness, without specifying exactly what these might be, although it implies enhanced financial performance (Tichy, Fombrun, \& Devanna, 1982; Cook \& Ferris, 1986). Another strand within the literature explicitly focused on improved financial performance as the ultimate measure of the effectiveness of HRM, but did not explain exactly how this relationship worked (Schuler \& MacMillan, 1984).

But many scholars have pointed out the problems of establishing the relationship between particular human resource practices and organizational outcomes (Truss, 2001). Generally speaking, it is recognized that adopting financial measures as the sole criterion of success is too limited, and a broader perspective should be introduced that additionally takes account of success in terms of the customer and employee constituencies, along the lines of the balanced scorecard (Kaplan \& Norton, 1992; Ulrich, 1997; Yeung \& Berman, 1997; Purcell, 1999).

There are plenty of empirical studies that have investigated whether firms utilizing particular HPWS managerial practices achieve a higher level of performance than traditionally managed firms (Tomer, 2001). Even though several theoretical and empirical problems remain, significant progress has been made in such systems and performance.

Theoretical (e.g., Lado \& Wilson, 1994; Jackson \& Schuler, 1995) and empirical HRM researchers (e.g., Huselid, 1995; MacDuffie, 1995) have led to a general consensus that the method used by firms to manage their workforce can have a positive impact on firm performance (Becker \& Huselid, 1997; Wright \& Boswell, 2002). The context in which organizations operate may limit or enhance the usefulness, distinctiveness and success of high performance work practices. There has been a lack of consensus regarding which HPWSs should be included. Studies address different outcomes ranging from financial performance (e.g., Huselid et al., 1997) or firm productivity (e.g., Guthrie, 2001) to employee commitment (e.g., Whitener, 2001), absenteeism (e.g., Guest \& Peccei, 1994) and customer satisfaction (e.g., Rogg, Schmidt., Shull, \& Schmitt, 2001). Vast differences also exist in the operationalization of such measures. Thus, there have been heated debates about the relationship between high performance work 
practices and firm performance (Wright \& Snell, 1998; Guest, 1997; Gerhart, Wright, McMahan, \& Snell, 2000). It is this logic of interdependent effects that makes the HPWS argument distinctive. It is related to a causal path in which worker outcomes mediate between HPWS practices and performance. Despite the importance of the causal relationship between these variables, the linkages of HPWS to employee outcomes and hence to organizational performance remain almost entirely untested.

\subsection{Person-Organization Fit}

Research on person-environment (P-E) fit generally supports the idea that a high level of P-E fit is related to positive individual and organizational outcomes. A number of researchers have mainly discussed the effects of P-O fit (e.g., Hoffman \& Woehr, 2006; Kristof-Brown, Zimmerman, \& Johnson, 2005; Kristof, 1996; Verquer, Beehr, \& Wagner, 2003). P-O fit addresses "the compatibility between people and the entire organization" (Kristof-Brown et al., 2005: 285). P-O fit is associated with various attitudes and behaviors. Kristof-Brown et al. (2005)'s meta-analysis presents the relationship between P-O fit and outcomes. Such outcomes include individual work attitudes (Vancouver \& Schmitt, 1991; Witt \& Nye, 1992; Witt, Hilton, \& Hellman; Witt \& Voss, 1995), intentions to quit (O'Reilly et al, 1991; Vancouver \& Schmitt, 1991; Vancouver, Millsap, \& Peters, 1994), organizational tenure (Bretz \& Judge, 1994), pro-social behavior (Posner et al., 1985; O’Reilly \& Chatman, 1986; Posner, 1992), and work performance (Bretz \& Judge, 1994; Downey et al., 1975). A review paper on P-O fit by Verquer et al. (2003) also reported that P-O fit is related to the intent to quit, job satisfaction and organizational commitment.

Theories regarding P-O fit have emphasized specific aspects of the employment experience that affect or are affected by individual-organizational congruence (Kristof, 1996; Kristof-Brown, 2000; Kristof-Brown et al., 2005). Arthur, Bell, Villado and Doverspike (2006) showed that P-O fit had only a small relation with job performance but strongly related with attitudinal outcomes such as job satisfaction, organizational commitment and turnover intentions. Chatman (1991) argued that values act as a guide or an overarching framework for conducting behavior in any given setting. Values drive attitudes, decisions, and ultimately actions.

The Attraction-Selection-Attrition (ASA) framework suggests that consideration of P-O fit during organizational entry is one of the primary influences in creating organizational homogeneity (Schneider, 1987). According to Chatman (1989), individual and organizational socialization practices have been supported as a second contributor to $\mathrm{P}-\mathrm{O}$ fit. With these aspects, it has been discussed that long-term outcomes attributed to P-O fit include turnover, work attitudes, pro-social behaviors, work performance, and organizational outcomes.

Although researchers examine the effects of fit on several outcomes, most studies center on positive outcomes for individuals, such as improved satisfaction and reduced intention to quit (Kristof, 1996). However, several theorists suggest that high levels of P-O fit produce negative outcomes at the organizational level (Schneider, 1987; Walsh, 1987; Schneider et al., 1994). Despite such contrasting arguments, there has been very little research conducted and published that investigates any direct organizational outcomes as a consequence of good or poor fit (Kristof, 1996; Schneider, 2000). Considering the limitation of previous studies, it is necessary to examine the linkage of P-O fit to organizational outcomes. By using a sample of twenty-seven organizations, Kwantes, Arbour and Boglarsky (2007) examined the relationship between organizational culture fit and group/ organizational-level outcomes such as teamwork, common goal orientation, and intra-organizational communication in six different national contexts. They argued that P-O fit may affect other higher-level outcomes such as group-level outcomes (e.g. teamwork and cooperation) which are deemed important to organizational leaders. Thus, researchers on P-O fit need to pay more attention to the higher-level outcomes and long-term organizational consequences of P-O fit (e.g., organizational recognition, adaptability, performance, and survival).

\subsection{High Performance Work Systems and Person-Organization Fit}

Although little research has been carried out on the relationship between HWPS and P-O fit (e.g., Boon, Den Hartog, Boselie \& Paauwe, 2011; Werbel \& Demarie, 2001, 2005), a great deal of implicit evidence exists about this relationship. In a broader sense, this relationship can be linked to HRM and organizational culture. Since P-O fit is highly associated with organizational culture, it also addresses person-environment (P-E) fit from a macro-level of analysis (Webel \& Demarie, 2005). P-O fit creates an organizational identity by establishing consistent values that permeate an organizational culture. P-E fit functions at both organizational and individual levels (Werbel \& Demarie, 2005). Specifically, at the organizational level, HR practices linked to each type of fit provide the organizational infrastructure with different organizational competencies (Werbel \& Gilliland, 1999).Thus, "if employees are proficient in their work throughout the organization, the productivity of individual employees will be high at the individual level of analysis while organizational profitability will be high at the organizational level of analysis" (Werbel \& DeMarie, 2005: 250). Since a misfit of the employee to the culture of an organization may not sustain 
long-term employment, it seems appropriate to examine the impact of $\mathrm{P}-\mathrm{O}$ fit as viewed from organizational culture on organizational outcomes.

HRM practices deliver P-O fit to employees at every stage of employment lifecycle (Bretz \& Judge, 1994; Autry \& Wheeler, 2005) through the dissemination of value-laden information. As such, socialization can be a significant effect on P-O fit. Through HRM systems, such as formal training and orientation, a "strong" organizational culture can be instilled in employees and consequently it can affect P-O fit.

According to Deal and Kennedy (1982), successful firms distinguish themselves from less successful ones through their clearly articulated and shared norms and values regarding organizational operation. Creating a strong organizational culture is a powerful tool to influence employee's behavior and to improve performance (Hartog \& Verburg, 2004). Guest (1994: 254) argues that, "Employees perform because they want to or at least feel obliged to rather than in response to financial incentives or bureaucratic requirements." Wilkins (1984) observes that the HRM can create an environment that encourages the development of a "strong" organizational culture (Ogbonna, 1992). He illustrated this point by citing examples of three HRM policies; selection, development and reward, and retention. Selection is, by far, the most widely cited HRM policy that facilitates the management of culture. As Tichy (1982) notes, organizations using HRM policies to develop a "strong culture" pay close attention to this process. The objective is to develop the selection process so that only those people are employed whose values are consistent, or could be made consistent, with the dominant values of the organization. By employing "like-minded" people, organizations are able to increase the strength of their culture and to reduce the possibility and consequences of undesired behaviors.

This paper assumes that workers in HPWSs are inclined to feel more similar to their co-workers than in other work systems. Guest (1994) suggests that HRM may contribute to both the emergence and the maintenance of shared patterns of norms, values and informal rules within organizations through selection, socialization and training procedures (Hartog \& Verburg, 2004). Thus, HRM practices, and more specifically HPWSs, may have an impact on organizational culture. One can also argue the reverse. The dominant culture may influence the HRM policy and practices adopted by organizations. The influence runs both ways. Another type of proposition worth exploring is whether performance is better where HRM practices and culture align. Research on all these perspectives is useful.

According to Werbel and DeMarie (2001), the organizational socialization process provides a useful framework to highlight which human resource functions are most relevant to a given type of P-E fit. In line with this research, an increasing body of work argues that the use of HPWSs can improve the knowledge, skills and abilities of a firm's current and potential employees and increase employees' motivation. With these results, reduced shirking and enhanced retention of quality employees are observed. Stated in this way, it is proposed that the HPWSs affect the $\mathrm{P}-\mathrm{O}$ fit positively, and that the relationship between HPWS and P-O fit provides important grounds for future research.

\section{Research Model and Agenda}

To what extent does the relationship between HPWSs and P-O fit influence organizational outcomes? Extant HR research has not paid much attention to the importance and influence of the employees' attitudes, behaviors and organizational outcomes. Considering this limitation, this study discusses the linkage of the P-O fit to HPWSs on organizational outcomes. The research model is shown in Figure 1. Although some empirical work has suggested that firms with HPWSs exhibit high P-O fit, the expectation that they should do leads to the propositions presented in this paper. The relationship of P-O fit to HPWS can be viewed from the perspective of strategic human resource management. For example, a formal job design program and enhanced selectivity will help ensure employee-job fit (Huselid, 1995).

One important issue for research in this area is the number of HR practices that should be included in HPWSs. Since there is little consensus regarding which high performance work practices should be included (e.g., Guthrie, 2001; Conway \& Monks, 2008), previous studies assess different outcomes ranging from financial performance (e.g., Huselid et al., 1997) and firm productivity (e.g., Guthrie, 2001) to employee commitment (e.g., Whitener, 2001), absenteeism (e.g., Guest \& Peccei, 1994) and customer satisfaction (e.g., Rogg et al., 2001). Drawing on earlier empirical studies (Arthur, 1994; Huselid, 1995; MacDuffie, 1995; Delery \& Doty, 1996; Becker \& Huselid, 1997; Ichniowski et al., 1997; Bae \& Lawler, 2000; Guthrie, 2001), this paper selects six HRM practices associated with $\mathrm{P}-\mathrm{O}$ fit and organizational outcomes, and then presents three propositions based upon them as follows.

Proposition 1: High performance work systems will be positively related to a high level of P-O fit. 
Training provides the opportunity to develop appropriate competencies for individuals and organizations (Lau \& Ngo, 2004). Examining technology-based firms, Spell (2001) found that technology influences the cognitive complexity of individuals, which requires employers to emphasize developmental activities and hence more extensive training. Formal training can have a positive impact not only on the skills, behavior scripts, motivation and outputs, but also on firm performance. In this sense, training is associated with P-O fit.

Proposition 1-1: Extensive formal training will be positively related to a high level of P-O fit.

Teamwork and decentralized decision making enhance familiarity and demand greater cohesion (Zacharotos et al., 2005). Various kinds of employee participatory programs are included here. For example, labor management participation teams (Arthur, 1994; Becker \& Huselid, 1997; Guthrie, 2001) and high participation and multiple teams (Ichniowski et al., 1997) are provided as a system (Way, 2002). Teamwork is linked to the P-O fit as follows.

Proposition 1-2: A higher level of teamwork and decentralized decision making will be positively related to higher P-O fit.

Extensive staffing refers to the extent that a firm's staffing process uses information gathered form several devices such as interviews, tests and work samples to evaluate job candidates (Way, 2002). Such a staffing process creates numerous barriers for job candidates but may result in the selection of individuals who possess superior skills and behavior scripts (Olian \& Rynes, 1984; Way \& Thacker, 2001).

Proposition 1-3: Highly selective staffing will be positively related to higher P-O fit.

Participation and communication are often stressed as part of HPWSs (e.g., Batt, 2002). It has been proposed that participation and information sharing can affect discretionary effort through their influence on employee skills and motivation and through organizational structures that provide employees with the ability to control how their roles are performed (Huselid, 1995). Quality of work programs, such as quality circles and labor-management teams, are all forms of participation that allow employees to have direct input into the production process. It is presumed that firms can increase the level of $\mathrm{P}-\mathrm{O}$ fit by providing participation and information sharing.

Proposition 1-4: A higher degree of participation and communication will be positively related to higher P-O fit.

Several authors have proposed that performance evaluation should form the basis for compensation and promotions and is, as such, important in attaining high performance (e.g., Huselid, 1995). Performance appraisals are tightly linked to employee compensation and promotion decisions based on employee merits. Delery and Doty (1996: 815) defined such performance appraisal as "the degree to which performance appraisals focused on the output or results measures rather than on behavioral measures." Thus, we expect the following:

Proposition 1-5: Higher focus on output results in performance appraisal will be positively related to higher P-O fit.

In the economics literature, group-based performance pay has been conceptualized as a way in which firms can align the desired goals of employees with those of the firm. Furthermore, the literature indicates that group-based performance can enhance employee retention and the motivation of employees to apply their skills and behavior script in their work-related activities.

The pay level of the workforce has been identified as playing a central role in the relationship between HPWS and firm performance (Becker \& Huselid, 1997). It has been proposed that the firms paying more than their competitors will attract a better quality of workforce. Here, the workforce is comprised of individuals possessing superior abilities, who are motivated to apply their abilities in their work-related activities, because they would not wish to lose these high paying jobs (Way, 2002). Performance-based pay reflects the extent of the linkage between performance and pay level.

Proposition 1-6: A higher level of performance-based pay will be positively related to higher P-O fit.

Although there are few studies on the relationship between HPWS, P-E fit and organizational outcomes such as organizational performance, we can expect that the employee's attitudes and behaviors mediate the relationship between HPWS and individual/ organizational performance. Boon et al.(2011) found that P-O fit and person-job (P-J) fit play both mediating and moderating roles in the relationship between perceived HR practices and employee outcomes such as job satisfaction, organizational commitment, turnover intention and organizational citizenship behavior (OCB).

The HPWS includes socialization process such as recruitment and selection. Cable and Parsons (2001) suggest that the content of socialization and the social environment of its delivery create strong perceptions of fit among employees, resulting in an increased overall perception of P-O fit. Likewise, Werbel and DeMarie $(2001,2005)$ 
addressed the close association of strategic human resource management with P-E fit. In this vein, the mediation effect of HRM on P-O fit can be proposed.

Proposition 2: P-O fit will mediate the relationship between high performance work systems and organizational outcomes.

As stated earlier, P-O fit affects organizational outcomes (e.g., Kwantes et al., 2007) as well as various individual outcomes such as work attitudes (e.g., Arthur et al., 2006; Kristof-Brown et al., 2005, Verquer et al., 2003), work performance and intentions to quit. Organizational outcomes include organizational reputation, adaptability, performance and organizational survival. Thus, we propose the following:

Proposition 3: A high level of P-O fit will be positively related to organizational outcomes such as organizational reputation, flexibility, performance and organizational survival.

\section{Concluding Remarks}

Insert Figure 1 about here

We should aim to tell the truth in our propositions, but we cannot aim to tell the whole truth. To advance new propositions is to propose a shift of focus, to recognize as central considerations that were previously neglected. In this paper, we have focused on the mediating effect of $\mathrm{P}-\mathrm{O}$ fit on the relationship between high performance work systems and organizational outcomes. Because the P-O fit is one of the most influential factors to enhance organizational performance.

Future research should consider the relationship between HPWSs, P-O fit and individual/ organizational outcomes at the multi-level. During the past thirty years, multilevel theory and research have increasingly become more common in industrial psychology, organizational behavior, and human resource management. Multi-level research can test such propositions, rigorously assessing the relationships among constructs at multi-levels of analysis. For example, alternative avenues should be pursued to disentangle the group and organizational cross-level factors that affect the link between HPWSs and individual outcomes. These factors include the group-level P-E fit, group personality and group cohesiveness/efficacy. Other factors that may influence P-O fit at the organizational level also need to be explored. Since firms with similar HR systems may exhibit different levels of P-O fit, the effects of various culture dimensions affecting P-O fit should probably be taken into account. Cultural traits associated with P-O fit may include collectivism vs. individualism, masculinity vs. femininity, power distance and uncertainty avoidance, among others. In addition to these traits, the cultural strength, diversity and flexibility of the organization are also worth pursuing. It is hoped that continuous attention will be paid to the social context of P-O fit and HRM that influences the relationship between these two constructs.

\section{References}

Arthur, J. B. (1992). The link between business strategy and industrial relations systems in American steel minimills. Industrial and Labor Relations Review, 45, 488-506. http://dx.doi.org/10.2307\%2F2524274

Arthur, J. B. (1994). Effects of human resource systems on manufacturing performance and turnover. Academy of Management Journal, 37, 670-687. http://dx.doi.org/10.2307\%2F256705

Arthur, W., Jr., Bell, S. T., Villado, A. J., \& Doverspike, D. (2006). The use of person-organization fit in employment decision making: An assessment of its criterion related validity. Journal of Applied Psychology, 91(4), 786-801. http://dx.doi.org/10.1037\%2F0021-9010.91.4.786

Autry, C. W., \& Wheeler, A. R. (2005). Post-hire human resource management practices and person-organization fit: A study of blue-collar employees. Journal of Managerial Issues, 17(1), 58-75.

Bae, J., \& Lawler, J. J. (2000). Organizational and HRM strategies in Korea: Impact on firm performance in an emerging economy. Academy of Management Journal, 43, 502-517. http://dx.doi.org/10.2307\%2F1556407

Batt, R. (2002). Managing customer services: Human resource practices, quit rates, and sales growth. Academy of Management Journal, 45, 587-597. http://dx.doi.org/10.2307\%2F3069383

Becker, B. E., \& Huselid, M. A. (1997). HR as a source of shareholder values: Research and recommendations. Human Resource Management, 39-47. http://dx.doi.org/10.1002\%2F\%28SICI\%291099-050X\%28199721\%2936\%3A1\%3C39\%3A\%3AAID-HRM8\%3E3. $0 . \mathrm{CO} \% 3 \mathrm{~B} 2-\mathrm{X}$

Becker, B. E., \& Huselid, M. A. (1999). Overview: Strategic human resource management in five leading firms. Human Resource Management, 38 , 287-301. 
http://dx.doi.org/10.1002\%2F\%28SICI\%291099-050X\%28199924\%2938\%3A4\%3C287\%3A\%3AAID-HRM2\%3E 3.3.CO\%3B2-C

Billsberry, J., Ambrosini, V., Moss-Jones, J., \& Marsh, P. (2005). Some suggestions for mapping organizational members' sense of fit. Journal of Business and Psychology, 19, 555-570. http://dx.doi.org/10.1007\%2Fs10869-005-4526-2

Bowen, D. E., Ledford, GE. Jr, \& Nathan, B. R. (1991). Hiring for the organization not the job. Academy of Management Executive, 5, 35-51. http://dx.doi.org/10.5465\%2FAME.1991.4274747

Bretz, R. D. Jr, \& Judge, T. A. (1994). Person-organization fit and the theory of work adjustment: Implications for satisfaction, tenure, and career success. Journal of Vocational Behavior, 44, 32-54. http://dx.doi.org/10.1006\%2Fjvbe.1994.1003

Cable, D. M., \& Parsons, C. K. (2001). Socialization tactics and person-organization fit. Personnel Psychology, 54, 1-23. http://dx.doi.org/10.1111\%2Fj.1744-6570.2001.tb00083.x

Chatman, J. A. (1989). Improving interactional organizational research: A model of Person-Organization fit. Academy of Management Review, 14, 333-349. http://dx.doi.org/10.2307\%2F258171

Chatman, J. A. (1991). Matching people and organizations: Selection and socialization in public accounting firms. Administrative Science Quarterly, 36, 459-484. http://dx.doi.org/10.2307\%2F2393204

Conway, E., \& Monks, K. (2008). HR practices and commitment to change: An employee-level analysis. Human Resource Management Journal, 18(1), 72-89. http://dx.doi.org/10.1111\%2Fj.1748-8583.2007.00059.x

Cook, D., \& Ferris, G. R. (1986). Strategic human resource management and firm effectiveness in industries experience decline. Human Resource Management, 25(3), 441-458. http://dx.doi.org/10.1002\%2Fhrm.3930250308

Deal, T. E., \& Kennedy, A. A. (1982). Corporate cultures. New York: Addison-Wesley.

Delery, J. E., \& Doty, D. H. (1996). Modes of theorizing in strategic human resource management: Tests of universalistic, contingency, and configurational performance predictions. Academy of Management Journal, 39, 802-835. http://dx.doi.org/10.2307\%2F256713

Downey, H. K., Hellriegel, D., \& Slocum, J. W. Jr. (1975). Congruence between individual needs, organizational climate, job satisfaction and performance. Academy of Management Journal, 18, 149-155. http://dx.doi.org/10.2307\%2F255634

Gerhart, B., Wright, P. M., McMahan, G. C., \& Snell, S. A. (2000). Measurement error in research on the human resources and firm performance relationship: Further evidence and analysis. Personnel Psychology, 53, 855-872. http://dx.doi.org/10.1111\%2Fj.1744-6570.2000.tb02420.x

Guest, D. E. (1994). Organizational psychology and human resource management: Towards a European Approach. European Work and Organizational Psychologist, 4, 251-270. http://dx.doi.org/10.1080\%2F13594329408410488

Guest, D. E. (1997). Human resource management and performance: A review and research agenda. International Journal of Human Resource Management, 8, 263-276. http://dx.doi.org/10.1080\%2F095851997341630

Guest, D. E., \& Peccei, R. (1994). The nature and causes to effective human resource management. British Journal of Industrial Relations, 32, 219-241. http://dx.doi.org/10.1111\%2Fj.1467-8543.1994.tb01042.x

Guthrie, J. P. (2001). High-involvement work practices, turnover, and productivity: Evidence from New Zealand. Academy of Management Journal, 44, 180-190. http://dx.doi.org/10.2307\%2F3069345

Hartog, D. N., \& Verburg, R. M. (2004). High performance work systems, organizational culture and firm effectiveness. Human Resource Management Journal, $14(1), \quad$ 55-78. http://dx.doi.org/10.1111\%2Fj.1748-8583.2004.tb00112.x

Hoffman, B., J., \& Woehr, D. J. (2006). A quantitative review of the relationship between person-organization fit and behavioral outcomes. Journal of Vocational Behavior, 68, 389-399. http://dx.doi.org/10.1016\%2Fj.jvb.2005.08.003

Huselid, M. A. (1995). The impact of human resource management practices on turnover, productivity, and corporate financial performance. Academy of Management Journal, 38, 635- 672. http://dx.doi.org/10.2307\%2F256741

Huselid, M. A., \& Jackson, S. E. (1997). Technical and strategic human resources management effectiveness as determinants of firm performance. Academy of Management Journal, 40, 171-188. 
http://dx.doi.org/10.2307\%2F 257025

Ichniowski, C., Shaw, K., \& Prennushi, G. (1997). The effects of human resource management practices on productivity: A study of steel finishing lines. American Economic Review, 87, 291-313.

Jackson, S. E., \& Schuler, R. S. (1995). Understanding human resource management in the context of organizations and their environment. Annual Review of Psychology, 46, 237-264. http://dx.doi.org/10.1146\%2Fannurev.psych.46.1.237

Judge, T. A., \& Ferris, G. R. (1992). Elusive criterion of fit in human resources staffing decisions. Human Resource Planning, 5, 47-67.

Kaplan, R, S., \& Norton, D. P. 1992. The balanced scorecard-measures that drive performance. Harvard Business Review, 70, 71-140.

Kristof, A. L. 1996. Person-Organization fit: An integrative review of its conceptualizations, measurement, and implications. Personnel Psychology, 49, 1-49. http://dx.doi.org/10.1111\%2Fj.1744-6570.1996.tb01790.x

Kristof-Brown, A. L. (2000). Perceived applicant fit: Distinguishing between recruiters' perceptions of person-job $\begin{array}{lllll}\text { and person-organization } & \text { fit. Personnel } & \text { Psychology, } & \text { 643-671. }\end{array}$ http://dx.doi.org/10.1111\%2Fj.1744-6570.2000.tb00217.x

Kristof-Brown, A. L., Zimmerman, R. D., \& Johnson, D. J. (2005). Consequences of individuals' fit at work: A meta-analysis of person-job, person-organization, person-group and person-supervisor fit. Personnel Psychology, 58, 281-342. http://dx.doi.org/10.1111\%2Fj.1744-6570.2005.00672.x

Kwantes., C. T., Arbour, S., \& Boglarsky, C. A. (2007). Organizational culture fit and outcomes in six national contexts: An organizational level analysis. Journal of Organizational Culture, Communications and Conflict, 11(2), 95-111.

Lado, A. A., \& Wilson, M. C. (1994). Human resource systems and sustained competitive advantage: A competency based perspective. Academy of Management Review, 19, 699-727. http://dx.doi.org/10.2307\%2F258742

Lau, C, M., \& Ngo, H. Y. (2004). The HR system, organizational culture, and product innovation. International Business Review, 13, 685-703. http://dx.doi.org/10.1016\%2Fj.ibusrev.2004.08.001

Lawler, E. E. (1992). Ultimate advantage: Creating the high involvement organization. Sloan Management Review, 33, 96-101.

Louis, M. R. (1980). Surprise and sense making: What newcomers experience in entering unfamiliar organizational settings. Administrative Science Quarterly, 25, 226-251. http://dx.doi.org/10.2307\%2F2392453

MacDuffie, J. P. (1995). Human resource bundles and manufacturing performance: Organizational Logic and flexible production systems in world auto industry. Industrial and Labor Relations Review, 48, 197-221. http://dx.doi.org/10.2307\%2F2524483

Messersmith J. G., \& Guthrie, J. P. (2010). High performance work systems in emergent organization: Implications for firm performance. Human Resource Management, 49(2), 241-264. http://dx.doi.org/10.1002\%2Fhrm.20342

Ogbonna, E. (1992). Organization culture and human resource management: Dilemmas and contradiction. In P. Blyton, \& P. Turnball, Reassessing human resource management (pp. 74-96). London: Sage Publications.

Olian, J. O., \& Rynes, S. L. (1984). Organizational staffing. Industrial Relations, 23, 170-183.

O'Reilly, C. A. III, \& Chatman, J. (1986). Organization commitment and psychological attachment: The effects of compliance, identification and internalization on prosocial behavior. Journal of Applied Psychology, 71, 492-499. http://dx.doi.org/10.1037\%2F\%2F0021-9010.71.3.492

O’Reilly, C. A. III, Chatman, J., \& Caldwell, D. F. (1991). People and organizational culture: A profile comparison approach to assessing person-organization fit. Academy of Management Journal, 34, 487-516. http://dx.doi.org/10.2307\%2F256404

Pfeffer, K. J. (1998). Seven practices of successful organizations. California Management Review, 96-124.

Posner, B. Z. (1992). Person-organization values congruence: No support for individual differences as a moderating influence. Human Relations, 45, 351-361. http://dx.doi.org/10.1177\%2F001872679204500403

Posner, B. Z., Kouzes, J. M., \& Schmidt, W. H. (1985). Shared values make a difference: An empirical test of corporate culture. Human Resource Management, 24, 293-309. http://dx.doi.org/10.1002\%2Fhrm.3930240305 
Preuss, G. A. (2003). High performance work systems and organizational outcomes: The mediating role of information quality. Industrial and Labor Relations Review, 56, 590-605. http://dx.doi.org/10.2307\%2F3590958

Purcell, J. (1999). Best practices and best fit: Chimera or cul-de-sac. Human Resource Management Journal, 9 , 26-41. http://dx.doi.org/10.1111\%2Fj.1748-8583.1999.tb00201.x

Reichers, A. E. (1987). An interactionist perspective on newcomer socialization rates. Academy of Management Review, 12, 278-287. http://dx.doi.org/10.2307\%2F258535

Rogg, K. L., Schmidt., D. B., Shull, C., \& Schmitt, N. (2001). Human resource practices, organizational capability, and customer satisfaction. Journal of Management, 27, 431-449. http://dx.doi.org/10.1016\%2FS0149-2063\%2801\%2900102-7

Rynes, S., \& Gerhart, B. (1990). Interviewer assessments of applicant "fit": An exploratory investigation. Personnel Psychology, 43, 13-35. http://dx.doi.org/10.1111\%2Fj.1744-6570.1990.tb02004.x

Schneider, B. (1987). The people make the place. Personnel Psychology, 40, 437- 453. http://dx.doi.org/10.1111\%2Fj.1744-6570.1987.tb00609.x

Schneider, B. (2001). Fits about fit. Applied Psychology: An International Review, 50, 141-152. http://dx.doi.org/10.1111\%2F1464-0597.00051

Schneider, B., Smith, D. B., \& Goldstein, H. W. (1994). The "dark side" of "good fit". Paper presented at the Ninth Annual Conference of the Society of Industrial and organizational Psychology, Nashville, TN.

Spell, C. S. (2001). Organizational technologies and human resource management. Human Relations, 54, 193-213. http://dx.doi.org/10.1177\%2F0018726701542003

Schuler, R. S., \& MacMillan, C. (1984). Gaining competitive advantage through human resource management practices. Human Resource Management, 23, 241-255. http://dx.doi.org/10.1002\%2Fhrm.3930230304

Tichy, N. M. (1982). Managing change strategically: The technical, political, and cultural keys. Organizational Dynamics, 11, 59-80. http://dx.doi.org/10.1016\%2F0090-2616\%2882\%2990005-5

Tichy, N. M., Fombrun, C. J., \& Devanna, M. A. (1982). Strategic human resource management. Sloan Management Review, 23, 47-61.

Truss, C. (2001). Complexities and controversies linking HRM with organizational outcomes. Journal of Management Studies, 38, 1121-1149. http://dx.doi.org/10.1111\%2F1467-6486.00275

Tomer, J. F. (2001). Understanding high performance work systems: The joint contribution of economics and human resource management. Journal of Socio-Economics, $30,33$. http://dx.doi.org/10.1016\%2FS1053-5357\%2801\%2900093-2

Ulrich, D. (1997). Measuring human resources: An overview of practice and a prescription for results. Human Resource Management, $303-320$. http://dx.doi.org/10.1002\%2F\%28SICI\%291099-050X\%28199723\%2936\%3A3\%3C303\%3A\%3AAID-HRM3\%3E 3.0.CO\%3B2-\%23

Vancouver J. B., \& Schmitt, N. W. (1991). An exploratory examination of person-organization fit: Organizational goal congruence. Personal Psychology, 44, 333-352. http://dx.doi.org/10.1111\%2Fj.1744-6570.1991.tb00962.x

Vancouver, J. B., Millsap, R. E., \& Peters, P. A. 1994. Multilevel analysis of organizational goal congruence. Journal of Applied Psychology, 79, 666-679. http://dx.doi.org/10.1037\%2F\%2F0021-9010.79.5.666

Youndt, M. A., Snell, S. A.., Dean, J. W., Lepak, D. P. (1996). Human resource management, manufacturing strategy, and firm performance. Academy of Management Journal, 39, 836-866. http://dx.doi.org/10.2307\%2F256714

Yeung, A, K., \& Berman, B. (1997). Adding value through human resources: Reorienting human resource measurement to drive business performance. Human Resource Management, 36, 321-335. http://dx.doi.org/10.1002\%2F\%28SICI\%291099-050X\%28199723\%2936\%3A3\%3C321\%3A\%3AAID-HRM4\%3E 3.3.CO\%3B2-2

Way, S. A. (2002). High performance work systems and intermediate indicators of firm performance within the US Small Business Sector. Journal of Management, 28, 765-785. http://dx.doi.org/10.1016\%2FS0149-2063\%2802\%2900191-5

Way, S. A., \& Thacker, J. W. (2001). The successful implementation of strategic human resource management 
practices: A Canadian survey. International Journal of Management, 18, 25-32.

Walsh, W. B. (1987). Person-environment congruence: A response to the Moos perspective. Journal of Vocational Behavior, 31, 347-352. http://dx.doi.org/10.1016\%2F0001-8791\%2887\%2990050-9

Walton, R. E. (1985). From control to commitment in the workplace. Harvard Business Review, 63, 77-85.

Werbel, J. D., \& Gilliland, S. W. 1999. The use of person-environment fit in the selection process. In G. Ferris (Ed.), Research in personnel and human resources management (Vol. 17, pp. 209-243). Greenwich, CT: JAI Press.

Werbel, J., \& DeMarie, S. M. (2001). Aligning strategic human resource management and person-environment fit: A strategic contingency perspective. Academy of Management Proceedings \& Member Directory, G1-G6. http://dx.doi.org/10.5465\%2FAPBPP.2001.6133186

Werbel, J., \& DeMarie, S. M. (2005). Aligning strategic human resource management and person-environment fit. Human Resource Management Review, 15, 247-262. http://dx.doi.org/10.1016\%2Fj.hrmr.2005.10.001

Whitener, M. (2001). Do 'high commitment' human resource practices affect employee commitment? A cross-level analysis using hierarchical linear modeling. Journal of Management, 27, 515-535. http://dx.doi.org/10.1016\%2FS0149-2063\%2801\%2900106-4

Wilkins, A. L. (1984). The creation of company cultures. Human Resource Management, 23, 41-60. http://dx.doi.org/10.1002\%2Fhrm.3930230105

Witt L. A., \& Nye, L. G. (1992). Goal congruence and job attitudes revisited. Paper presented at the Seventh Annual Conference of the Society for Industrial and Organizational Psychology. Montreal, Canada.

Witt L. A., Hilton, T. F., \& Hellman, C. M. (1993). Person-organization fit and job satisfaction: A social exchange perspective. Paper presented at the Annual Meeting of the Southwest Academy of Management, New Orleans, LA.

Witt L. A., \& Voss, E. (1995). Person-organization fit, customer focus and commitment. Paper presented at the Tenth Annual meeting of the Society for Industrial and Organizational Psychology, Orlando, FL.

Wood, S., Van Veldhoven, M., Croon, M., \& de Menezes, L. M. (2012). Enriched job design, high involvement management and organizational performance: The mediating roles of job satisfaction and well-being. Human Relations, 65(4), 419-445. http://dx.doi.org/10.1177\%2F0018726711432476

Wright, P. M., \& Snell, S. A. (1998). Toward a unifying framework for exploring fit and flexibility in strategic human resource management. Academy of Management Review, 23, 756-772. http://dx.doi.org/10.2307\%2F259061

Wright, P. M., \& Boswell, W. R. (2002). Desegregating HRM: A review and synthesis and micro and macro human resource management. Journal of $247-276$. http://dx.doi.org/10.1016\%2FS0149-2063\%2802\%2900128-9

Zacharatos, A., Barling, J., \& Iverson, R. D. (2005). High-performance work systems and occupational safety. Journal of Applied Psychology, 90, 77-93. http://dx.doi.org/10.1037\%2F0021-9010.90.1.77

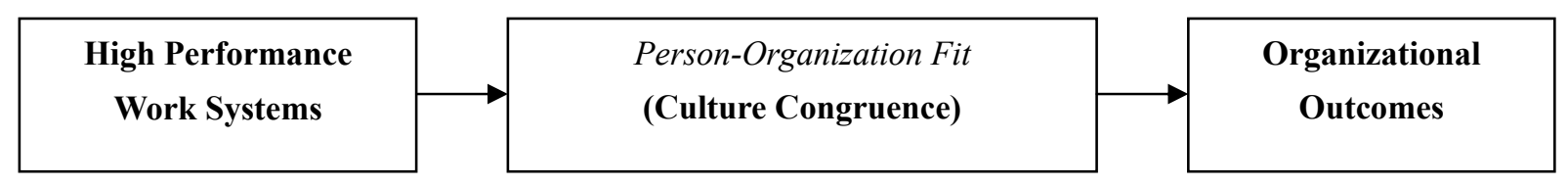

Figure 1. Research Model 